\title{
Application of Tissue Culture Technique Integrated with Thermotherapy, Plant Extracts and Fungal Culture Filtrates for Controlling Certain Potato Viruses
}

\author{
Mohamed, Safynaz, A.E.; O.A. Abdalla*; Amal I. Eraky and F.G. Fahmy
}

Department of Plant Pathology, Faculty of Agriculture, Assiut University, Assiut, Egypt

*Corresponding author: osama-mohammad@utulsa.edu

Received on: $28 / 11 / 2016$

Accepted for publication on: 14/12/2016

\begin{abstract}
Plant diseases caused by insect-transmitted viruses are among the most serious potato production problem. Alfalfa mosaic virus (AMV) and Potato virus $Y$ (PVY) consider among the most common viruses greatly infecting potato crop in Assiut governorate and result in a serious losses in potato production as well as reduction of potato quality. Results revealed that using meristem culture technique alone was not sufficient to produce virus free potato plantlets, but when this technique integrated with thermotherapy it proved high efficiency to eradicate the viral agents. Also, aqueous plant extract of Barnoof (Pluchea discorodis) in the nutrient media used in meristem culture technique (Murashige and Skoog) could be useful to increase the efficiency of this technique to produce virus free plantlets.

Culture filtrates of Oyster mushroom Pleurotus ostreatus L. or entomopathogenic fungus Ascosphaera apis have an inhibitory effects against Alfalfa mosaic virus and using these culture filtrates either separately or simultaneously resulted in significant reduction of local lesions produced in indicator plants Chenopodium sp.
\end{abstract}

Keywords: Alfalfa mosaic virus, Potato virus $Y$, Potato.

\section{Introduction}

Potato crop grown in Assiut is subjected to infection with many viruses resulted in serious losses in potato production as well as quality (Abdalla et al. 2015). Diseases caused by plant viruses consider one of the most serious production problem threaten potato crop (Zehnder et al., 2009). Among these viruses Alfalfa mosaic virus (AMV) and Potato viruses $Y$ are responsible for severe viral like symptoms on potato crop in Assiut governorate (Abdalla et al. 2016).

One of the most effective strategies to reduce losses of viral diseases is using plant source free of viral infection and thus reducing initial viral inoculum in the field and thus signifi- cantly reduce disease incidence of these viruses in potato field.

Using meristem culture technique has proved highly efficiency in producing virus free plants that comes from infected plants (Mellor and Stace-Smith 1970; Debergh and Maene 1981; Klein and Levington 1982; Dunbar et al. 1993). This method takes advantage of the fact that many viruses fail to invade the meristematic region (Parmessur and Saumtally 2001). Many factors can affect the efficiency of meristem technique method to obtain virus free plantlets: meristem size, culture media, effect of thermo therapy and/or chemotherapy, and growing conditions (Cassels 1987; Malaurie et al. 1998). 
Thermo and chemotherapy coupled with meristem culture technique could be used when meristem culture technique alone fails (Kartha 1986; Brown et al. 1988).

Viruses vary in the ease which they can be eradicated through thermotherapy (Kassins, 1957), Potato leaf roll virus (PLRV) is the most heat-sensitive while, Cucumber mosaic virus could be eradicated by using higher temperature (Walkey and Freeman 1977).

Using antiviral compound like certain plant extract integrated with meristem culture technique can also increase the possibility of virus eradication from plants, Allam et al. (2000) found that 6benzylaminopurine (BAP) supplemented to nutritive medium cab eradicate cucumber mosaic virus (CMV) from three different cultivars (Grand Naine, Dwarf and Williams), while Fahmy and Mohamed (1989) reported that Buphanisine inhibited Potato $X$ virus (PXV), Potato $S$ virus (PSV) and Potato virus $Y$ virus (PYV) when applied in apical meristem technique. Many plant extracts have an inhibitory effects against plant viruses like Mirabilis jalapa, which containing a ribosome inactivation protein (RIP) called Mirabilis antiviral protein (MAP) and has inhibitory effects against Potato virus $Y$ (Vivanco et al. 1999).

This study is trying to integrate thermotherapy method and antiviral agents like plant extract or fungal cultural filtrates with meristem culture technique in order to obtain virus free plantlets and thus control viral diseases in potato crop in Assiut governorate.

\section{Materials and Methods}

Virus source: Potato tubers (Burna variety) were tested using serological and Molecular identification tools as described by Abdalla et.al. (2016) and found to be infected with Potato virus $Y$ and Alfalfa mosaic virus.

Heat Therapy: These infected potato tubers were subjected to heattherapy in an incubator at $37^{\circ} \mathrm{C}$ for 6 weeks for viral inactivation according to the method described by Fahmy and Larina, (1982). Sixty meristem were used from each treatment. Plantlets produced from nodal cuttings were subjected to serological to determine viral infection percentages as described by Abdalla et al. (2016).

Tissue culture technique: The medium developed by Murashige and Skoog (1962) (MS) for tobacco tissue culture was used in culturing apical meristems on agar as well as cell suspension cultures in liquid media. Chemical contents of media were dissolved in distilled water. The stock solutions were added, then $\mathrm{pH}$ of the medium was adjusted to 5.6-5.8 and the agar was melted at mild heating and immediately distributed into test tubes $15 \mathrm{~cm}$ in length at rate of $10 \mathrm{ml}$ per tube or $30 \mathrm{ml}$ per flasks $(150 \mathrm{ml}$ in volume), which then sealed with cotton stoppers and covered with aluminum foil and autoclaved.

Apical meristem method: Sprouts from Burna potato variety after heat therapy treatment at $37^{\circ} \mathrm{C}$ for 6 weeks were chosen as starting materials.

Choice of explants: Sprouts were rinsed in water then treated with $0.5 \%$ mercuric chloride for $5 \mathrm{~min}-$ utes. After each step, the explants were washed thoroughly with sterilized water. Leaves surrounding the meristem of their apical buds were removed with sterilized thin needle 
and the shoot tip about (0.5-0.8 $\mathrm{mm})$ containing the meristem dome and 23-leaf primordial were dissected under a stereoscopic microscope. Meristems were transferred to tubes containing $10 \mathrm{ml}$ of solid modified MS medium.

Preparation of Plant extract: Plant tissues of Barnoof, (Pluchea discoridid) family Asteraceae from two different parts (flowers, leaves) at flowering stage were collected and let to air dryness. Then 40, 20, and 10 grams of dried materials of the aforesaid plants were rinsed in one liter of distilled water in a refrigerator over night at $4^{\circ} \mathrm{C}$., then obtainable plant aqueous extracts were filtered with double layer of sterile cheesecloth .

Effect of barnoof aqueous plant extracts in vitro: Barnoof plant extracts of 10, 20 and 40 gram /1 concentration were sterilized through Seitez filter and one, two or four $\mathrm{ml}$ litter of each plant extracts were added to a separate 1 litter of sterilized modified Murashige and Skoog medium. After that tubes or flacks containing medium with aqueous extracts were cultivated with nodal potato cuttings infected with Alfalfa mosaic virus and potato virus $Y$ and then were kept in an incubator at 20 ${ }^{\circ} \mathrm{C}$ with illumination period 16 hours and darkness for 8 hours until nodal cuttings grow will and forming plantlets. Plantlets produced from nodal cuttings were subjected to serological to determine viral infection percentages as described before.

Culture filtrates of Pleurotus ostreatus L. and Ascosphaera apis L: Flasks containing $150 \mathrm{ml}$ of Mura- shige and Skoog Liquid medium was inoculated by fungus disk $(7 \mathrm{~mm}$. in diameter) from each of tested fungi Oyster mushroom (Pleurotus ostreatus $L$ or entomopathogenic fungus Ascosphaera apis and then incubated in an incubator at $27^{\circ} \mathrm{C}$ for 15 days. The obtainable fungal growth using Watman filter paper was filtered and culture filtrates was collected and kept in the refrigerator at $4{ }^{\circ} \mathrm{C}$ until use. This crude mixed culture filtrates had been used without any dilution or it was diluted with sterilized distilled water as follows: $(1: 1,1: 2$ and $1: 3)$ and then tested for its inhibitory effect against the aforesaid virus in vivo which had been done in the greenhouse.

Testing of fungal culture filtrate in vivo: Two drops of the tested inhibitor was mixed with two drops of infectious crude sap which containing AMV and by using cotton pad the indicator leaves (Chenopodium amaranticolor) was mechanically inoculated with this mixture as well as with only infected sap without culture filtrate inhibitors and number of local lesion were recorder one week after inoculation.

\section{Experimental Results}

Results in Table 1. showed that using heat therapy with apical meristem method gave $15.90 \%$ of virusfree plantlets, while using apical meristem method alone without heat therapy did not result in producing any virus free plantlets of Burna tested potato variety from AMV and PVY. 
Table 1. Using heat therapy integrated with apical meristem technique $f$ to control Alfalfa mosaic virus and Potato virus $Y$

\begin{tabular}{|c|c|c|c|c|c|}
\hline $\begin{array}{c}\text { Potato } \\
\text { varieties }\end{array}$ & $\begin{array}{c}\text { Tested } \\
\text { viruses }\end{array}$ & \multicolumn{2}{|c|}{ \% of Survivors plants* } & \multicolumn{2}{c|}{$\%$ of cured plants } \\
\hline \multirow{2}{*}{ Burna } & $\begin{array}{c}\text { AMV } \\
\text { and PVY }\end{array}$ & $\begin{array}{c}\text { Untreated } \\
\text { Plants }\end{array}$ & $\begin{array}{c}\text { Treated plants } \\
\text { with Heat }\end{array}$ & Untreated Plants & $\begin{array}{c}\text { Treated plants } \\
\text { with Heat }\end{array}$ \\
\cline { 2 - 6 } & 76.66 & 73.33 & 0.0 & $15.90^{* *}$ \\
\hline
\end{tabular}

*Sixty meristems were used for each treatment.

** Sig. at 0.05

Data in Table 2. showed that adding aqueous extract of Barnoof to the cultivated modified (M\&S) medium $\mathrm{M}_{25}$ able to free potato calluses from certain viruses after cultivation of callus segments on the aforesaid medium containing aqueous extract of Barnoof. However, exposure time for 45 days on such medium led to freeing some plantlets of Burna potato variety from tested viruses.

Table 2. Effect adding of aqueous extract of Barnoof (Pluchea discoridis L.) in $\mathbf{M}_{25}$.

\begin{tabular}{|c|c|c|c|c|}
\hline $\begin{array}{c}\text { Potato } \\
\text { variety }\end{array}$ & $\begin{array}{c}\text { Concentration of Barnoof } \\
\text { extract }\end{array}$ & $\begin{array}{c}\text { Number of } \\
\text { survivors }\end{array}$ & $\begin{array}{c}\text { Number of } \\
\text { cured plants }\end{array}$ & $\begin{array}{c}\% \text { of cured } \\
\text { plants }\end{array}$ \\
\hline \multirow{3}{*}{ Burna } & $\begin{array}{c}\text { (Control) without aqueous } \\
\text { extract of Barnoof }\end{array}$ & 42 & 0.0 & 0.0 \\
\cline { 2 - 5 } & $1 \mathrm{ml}$ & 42 & 13 & 30.95 \\
\cline { 2 - 5 } & $2 \mathrm{ml}$ & 39 & 19 & 48.71 \\
\cline { 2 - 5 } & $4 \mathrm{ml}$ & 39 & 30 & 76.92 \\
\hline
\end{tabular}

Twenty meristems were used for each treatment.

L.S.D at $5 \%$

A $($ Number of survivor plants $)=2.03 \& B($ Number of cured plants $)=1.243$

Data in Table 3. showed that using culture filtrate of Ascosphaera apis L. or Pleurotus ostreatus L. either separately or in combination significantly reduced the number of local lesion produced on Chenopodium sp. due to AMV infection. The best result was obtained when the two cultured filtrates used simultaneously in mixture and resulted in the least number of local lesions, followed by treatment with Ascosphaera apis L. alone then Pleurotus ostreatus L. 
Table 3. The inhibitory effect of culture filtrates of Oyster mushroom Pleurotus ostreatus L. and entomopathogenic fungus $A s-$ cosphaera apis L. on Alfalfa mosaic virus:

\begin{tabular}{|c|c|}
\hline Culture filtrates & $\begin{array}{c}\text { Means of local le- } \\
\text { sions induced on } \\
\text { Chenopodium ama- } \\
\text { ranticolor } \mathbf{~ L}\end{array}$ \\
\hline Ascosphaera apis L. & 9 \\
\hline Pleurotus ostreatus L. & 12.25 \\
\hline $\begin{array}{c}\text { Pleurotus ostreatus } \text { L. } \\
\text { Ascosphaera apis } \text { L. }\end{array}$ & 2.25 \\
\hline $\begin{array}{c}\text { Control: (Leaves inocu- } \\
\text { lated only with AMV } \\
\text { without culture filtrate })\end{array}$ & 45 \\
\hline
\end{tabular}

L.S.D: $\quad 5 \%=4.61$

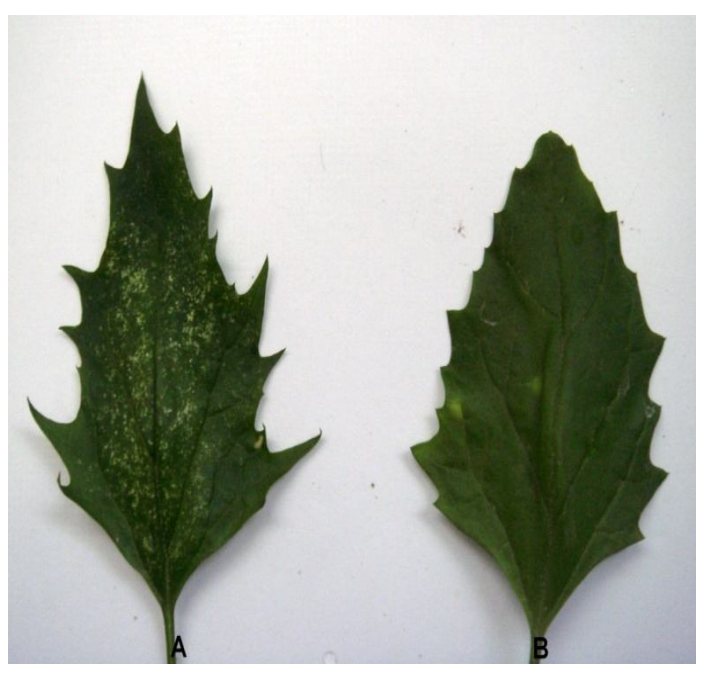

Figure 1. Effect of mixed culture filtrates Pleurotus ostreatus L. and Ascosphaera apis L. fungi on the inactivation of (AMV) local lesions numbers on (Chenopodiun amaranticolor L.). (A) control \& (B) infectious sap of (AMV) plus mixed culture filtrates .

\section{Discussion}

Control of viral diseases remains very difficult due to absence of direct control method to reduce these diseases, in addition to the harmful effects of insecticides to control the insect vectors of these viruses. This work was directed to control AMV and PVY viruses in potato through reducing initial sources of virus inoculum in the field. This could be done through generating virus free potato plantlet by using tissue culture techniques integrated with other method including thermotherapy, plant extract and fungal culture filtrates.

Results reported herein revealed that using apical meristem method without heat therapy did not produce any free potato plants from Alfalfa mosaic virus and Potato virus $Y$. However, using heat therapy with apical meristem method gave 15.90 $\%$ of virus-free plantlets. These results are in agreement with the findings of Pennazio et al. (1976); Lozoya and Dawson, (1982); Lozoya and Merlin-Lara, (1984) who reported that thermotherapy and meristem culture are commonly used for the production of virus-free stocks of potatoes.

Plant extract of Barnoof ( $P$. discoridis L.) was used for inactivating (AMV). preliminary tests showed an inhibitory effect on AMV and PVY viruses and Barnoof (P. discoridis L.) plant extracts was superior in its effect to minimize the production of local lesions produced by AMV on the inoculated leaves of aforesaid indicator plants. These data are in harmony with previous results obtained by (Vivanco et al. 1999). Plant extract may contain viral inhibitors that mimic the virus-associated protein (VAP) and bind to the cellular receptors or blocking a pocket on the surface of the virus that controls the uncoating process, these processes may 
thwart its reproductive cycle and inhibited viral pathogens (Lerch, 1987).

Using culture filtrate of certain fungi showed high efficiency in reducing local lesions produced in indicator host Chenopodium sp. This effect may be due to presence of antiviral compound in these culture filtrates. Many workers such as (Osborn and Hartley, 1990; Prestle, et.al., 1992a; and Stübler, and Buchenauer, 1996) have indicated that antiviral agents are one class of a larger group which can control plant viruses.

\section{References}

Abdalla, O. A., Eraky, A. I., Mohamed, S. A. E., and Fahmy, F. G. 2016. Molecular identification of viruses responsible for severe symptoms on Potato (Solanum sp.) growing in Assiut Governorate (Upper Egypt). Int. J. Virol. Stu. and Res. 4: 29-33.

Abdalla, O. A., Mohamed, S. A. E., Eraky, A. M. I., and Fahmy, F. G. 2015. Genetic comparison between coat protein gene of Alfalfa mosaic virus isolate infecting potato crop in Upper Egypt and worldwide isolates. Int. J. Virol. 11:11 2-122.

Allam E.K., Othman, B.A.; Sawy, E.I. and Thabet S.D. 2000. Eradication of Banana bunchy top virus (BBTV) and Banana mosaic virus (BMV) from diseased banana plants, Ann. Agric. Sci., 45(1):3348.

Brown, G.R., Kwiatkowski, S.; Martin, M.W. and Thomas, P.E. 1988. Eradication of PVS from potato clones through excision of meristems from in vitro, Heat-treated shoot tips. Am. Potato J., 65:633638.

Cassels, A.C. 1987. In vitro induction of virus-free potatoes by chemotherapy. In:'Biotechnology in agricul- ture and forestry. Vol.3:Potato." (Eds.) Y.P.S. Bajaj. SpringerVerlag Berlin pp. 40-50.

Debergh, P.C. and Maene, L.J. 1981. A scheme for commercial propagation of ornamental plants by tissue culture. Scie. Horti., 14: 335-345.

Dunbar, K.B., Pinnow, D.L.; Morris, J.B. and Pittman, R.N. 1993. Virus elimination from interspecific Arachis hybrids. Plant Dis., 77:517520.

Fahmy, F.G.M. and Larina, E.I. 1982. Sanitation of potato from mosaic group viruses using the method of apical meristem. Proceedings of All. Uni. Res. Inst. P1. Prot. Leningrad p.62.

Fahmy, F.G. and Mohamed, M. S. 1989. Buphanisine as a new plant antiviral agent. Assiut J. Agric. Sci. 20, 279-292.

Kartha, P, M, Samydurai, P., Subbaiyan, B., Thangapandian, V., and Binu, T. 1986. In vitro propagation of a rare succulent medicinal plant Caralluma diffusa (Wight) N.E.Br. Res. in Plant Biol., 308-17, 2013.

Kassins, B. 1957. The use of tissue culture to produce virus-free clones from infected potato varieties. Ann. Appl. Biol. 45:422- 427.

Klein, R.E and Levington, C.H. 1982. Eradication of Potato virus $X$ from potato by ribavirin treatment of cultured potato tips. Am. Potato J., 59:359-365.

Lerch, K.1987. Monophenol monooxygenase from Neurospora crassa. Methods Enzymol.142,165-169.

Lozoya, S. H. and Dawson, W.O. 1982. The use of constant andalternating temperature and tissue culture to obtain PVS- plants. Amer Potato J., 59: 221-230.

Lozoya, S.H. and Merlin-Lara, O. 1984. Thermotherapy and tissue culture for elimination of Potato virus $X$ (PVX) in mexican potato cultivars 
resistant to late blight. Amer Potato J., 61: 735- 739.

Malaurie B, Trouslot M. F., Engelmann F, Chabrillange N. 1998. Effect of pretreatment conditions on the cryopreservation of in vitrocultured yams (Dioscorea alata 'Brazo Fuerte' and D. bulbifera 'Noumea Imboro') shoot apices by encapsulation Cryoletters 19:15-26.

Mellor, F.C., and Stace-Smith, R. 1970. Virus strain differences in eradication of Potato virus $X$ and $S$. Phytopathology, 60:1587-1590.

Murashige, T. and Skoog, F. 1962. A revised medium for rapid growth and bioassays with tobacco tissue culture. Physiol., 15: 373-497.

Osborn, R.W. and Hartley, M. R. 1990. Dual effects of the ricin A chain on protein synthesis in rabbit reticulocyte lysate. Inhibition of initiation and translocation. Eur $\mathrm{J}$ Biochem. 24; 401-407.

Parmessur Y. and Saumtally, A. 2001. Elimination of Sugarcane yellow leaf virus and Sugarcane bacilliform virus by tissue culture. Food and Agricultural Research Council, Réduit, Mauritius, pp. 127-133.

Pennazio, S., Appiano, A., Vecchiati, M. and D'Agostino, G. 1976. Thiamine requirement of potato meris- tem tips cultured in vitro. Physiol Veg., 14: 121-131.

Prestle, J., Hornung, E., Schonfelder, M. and Mundry, K.W. 1992. Mechanism and site of action of a ribosome-inactivating protein type 1 from Dianthus barbatus wich inactivates Echerichia coli ribosomes. FEBS Letters 297,250-2.

Stübler,D and Buchenauer, H.1996. Antiviral Activity of the Glucan Lichenan (Poly- $\beta(1 \rightarrow 3, \quad 1 \rightarrow 4) \mathrm{D}-$ anhydroglucose). J. Phytopath. 144 (1):37-43.

Vivanco, J.M, Querci, M. and Salazar, L.F. 1999. Antiviral andantiviroid activity of MAP-containing extracts from Mirabilis jalaparoots. Plant Dis., 83:1116-1121.

Walkey, D.G.A. and Freeman, G.H. 1977. Inactivation of Cucumber mosaic virus in cultured tissues of Nicotiana rustica by diurnal alternating periods of high and low temperature. Ann. of App. Biol, 87:375-382.

Zehnder, G. W., Yao, C., Murphy,J. F., Sikora, E. J., Kloepper, J. W., Schuster, D. J., and Polston, J. E. 2009. Microbe-induced Resistance: A Novel Strategy for Control of Insect-transmitted Diseases in Vegetables. Radcliffe's IPM world Textbook, University of Minnesota. 
تطبيق استعمال المعاملات الحرارية والمستخلصات النباتية و الر اشحات الفطرية في تنقية

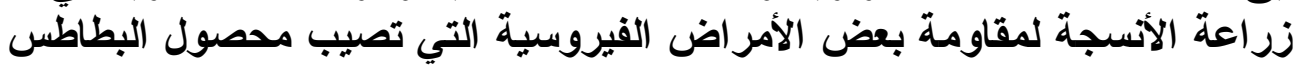

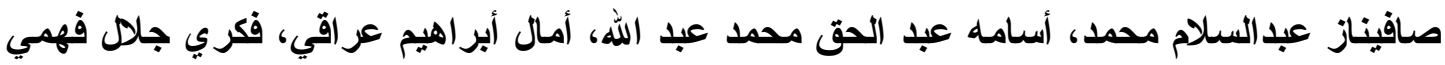

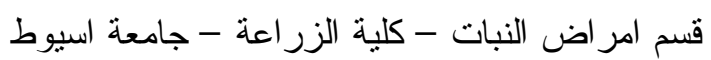

الملخص

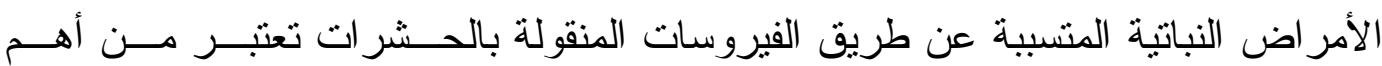

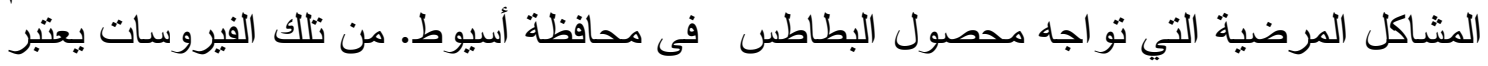

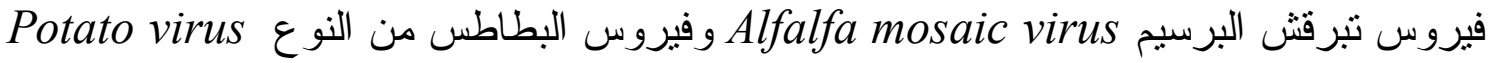

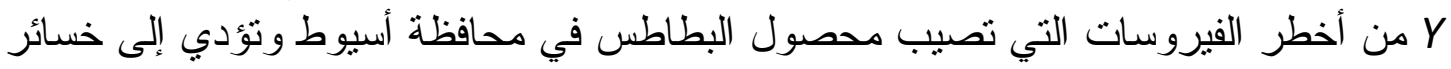

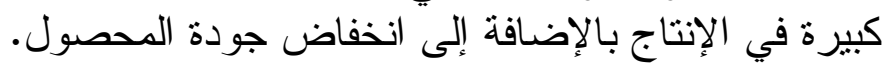
هذه الدراسة تهدف إلى دراسة إمكانية مقاومة عن تلإلك الأمر اض الفيروسية عن طريق

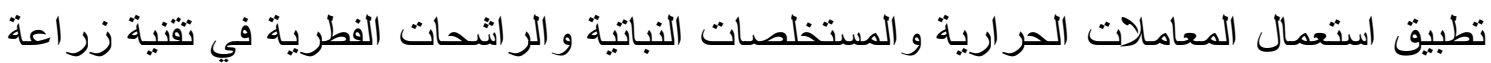
الأنسجة.

أوضحت نتائج هذه الدراسة أن استخدام تقنية زر اعة الأنسجة بدون المعاملات الحرارية

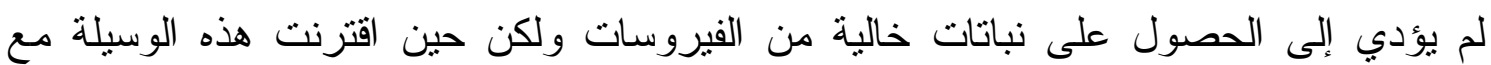

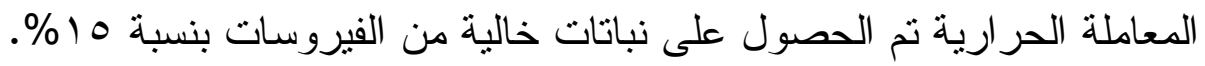

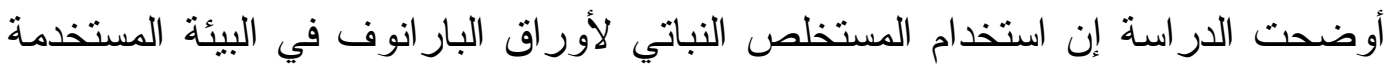

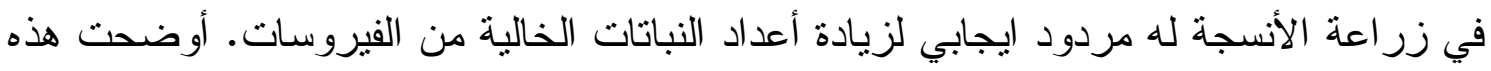

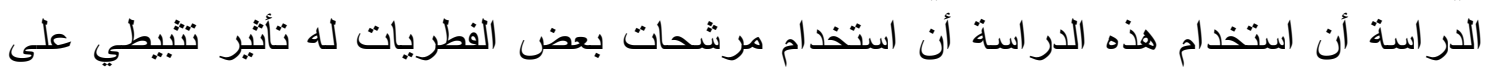

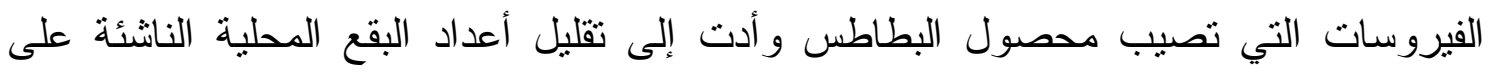

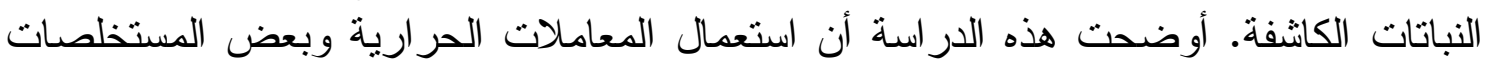

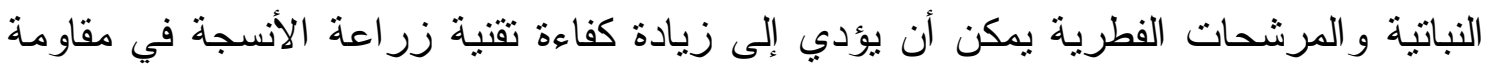
الأمر اض الفيروسية الني تصيب محصول الفئرن البطاطس. 